\title{
Novel Compound SK-1009 Suppresses Interleukin-6 Expression through Modulation of Activation of Nuclear Factor-KappaB Pathway
}

\author{
Misato Shimura, ${ }^{a, d}$ Masafumi Yamamoto, ${ }^{b}$ Gen Fujii, ${ }^{a}$ Mami Takahashi, ${ }^{b}$ Masami Komiya, ${ }^{a}$ \\ Nobuharu Noma ${ }^{a, d}$ Sei-ichi Tanuma, ${ }^{d}$ Akinori Yanaka, ${ }^{c, \dagger}$ and Michihiro Mutoh*,a \\ ${ }^{a}$ Division of Cancer Prevention Research, National Cancer Center Research Institute; ${ }^{b}$ Central Animal Division, \\ National Cancer Center Research Institute; 5-1-1 Tsukiji, Chuo-ku, Tokyo 104-0045, Japan: ${ }^{c}$ Faculty of \\ Pharmaceutical Sciences, Tokyo University of Science; and ${ }^{d}$ Division of Biochemistry, Faculty of Pharmaceutical \\ Sciences, Tokyo University of Sciences; 2641 Yamazaki, Noda, Chiba 278-8510, Japan. \\ Received June 29, 2012; accepted September 18, 2012; advance publication released online September 27, 2012
}

\begin{abstract}
Although interleukin-6 (IL-6) is an important biological mediator playing an indispensable role in inflammation and cancer, few inhibitors and suppressors are known. In the present study, the underlying mechanisms of a novel chemically synthesized compound SK-1009, which has suppressive properties on IL-6 production in human macrophage cells, were examined. SK-1009 suppressed IL-6 mRNA levels in human colon cancer cells. Thus, the influence of SK-1009 on transcription factor, nuclear factor-kappaB (NF- $\kappa$ B), which is involved in expression of the IL-6 gene was assessed. SK-1009 was found to suppress degradation of $\mathrm{I}-\boldsymbol{} \mathrm{B}$, an NF- $\kappa \mathrm{B}$ inhibitory factor, and consequently inhibited the NF- $\kappa \mathrm{B}$ activation pathway. The inhibitory property was almost the same as other NF- $\kappa$ B inhibitors, such as 5HPP-33. Thus, SK-1009 exerts a potent inhibitory effect on IL-6 expression, apparently mediated by modulation of activation of NF- $\kappa$ B transcription factor.
\end{abstract}

Key words SK-1009; interleukin-6; nuclear factor-kappaB; colon

Interleukin 6 (interferon beta 2, IL-6) is a cytokine primarily produced at acute and chronic inflammation sites, and acts as both a pro-inflammatory and anti-inflammatory cytokine. IL-6 stimulates acute phase protein synthesis and neutrophil production in bone marrow. Moreover, it supports $\mathrm{B}$ cell growth and antagonizes regulatory T cells. IL-6 elicits its signals through a receptor complex of IL-6R $\alpha$ and gp130. The function of the IL- 6 gene is implicated in a wide variety of inflammation-associated diseases, such as diabetes mellitus, systemic juvenile rheumatoid arthritis and cancer. ${ }^{1-3)}$

Patients with advanced and/or metastatic cancer have been reported to show high levels of IL-6 in their blood. ${ }^{4-8)}$ In animal models, Apc-deficient Min mice lacking the IL-6 gene decreased overall polyp numbers by $32 \%$ compared with IL-6 wild Min mice. The Min mouse has a mutation in the Apc tumor suppressor gene and develops intestinal polyps, and shows a 10-fold increase in serum IL-6 levels at 26 weeks of age. ${ }^{9}$ On the other hand, pitavastatin is a novel chemically synthesized hydroxymethylglutaryl (HMG)-CoA reductase inhibitor, which was demonstrated to reduce intestinal polyp formation in Min mice. In the pitavastatin experiment, serum IL-6, leptin, and MCP-1 levels were decreased at a dose of 40 ppm. ${ }^{10)}$ Thus, IL- 6 has been suggested to play an important role in colon/intestinal carcinogenesis.

Hence, there is an interest in developing anti-IL-6 agents for therapy against inflammation and cancer. ${ }^{11,12}$ For instance, tocilizumab has been approved as a therapeutic agent for systemic juvenile rheumatoid arthritis. Indeed, it may be difficult to develop a small molecule, that selectively suppress IL-6 expression, but there are a very few small molecules reported to suppresses IL-6 expression. One of them is SK-1009 (Fig.

\footnotetext{
The authors declare no conflict of interest.

${ }^{\dagger}$ Present address: Hitachi Medical Education and Research Center, Division of Clinical Medicine, Faculty of Medicine, University of Tsukuba, 2-1-1 Jonan-cho, Hitachi, Ibaraki 317-0077, Japan.
}

1). SK-1009 is a chemically synthesized compound, obtained from a screening of compound library. It has been reported to inhibit lipopolysaccharide (LPS)-induced IL-6 production in human macrophage cells, THP-1 (information from international patent WO2007/091313). However, underlying mechanisms of IL-6 suppression by SK-1009 are not elucidated in detail.

In the present study, we aimed to clarify the mechanisms by which SK-1009 suppresses IL-6 expression. We have investigated the effects of SK-1009 on IL-6 and tumor necrosis factor $\alpha(\mathrm{TNF} \alpha)$ expression levels in a human colon cancer cell line stimulated by TNF $\alpha$. We found that SK-1009 effectively suppressed IL-6 expression through inhibition of activation of a transcription factor, nuclear factor-kappaB (NF- $\kappa \mathrm{B})$.

\section{MATERIALS AND METHODS}

Cells and Test Compounds Human colon cancer cell lines, HCT116, RKO and SW480 cells (American Type Culture Collection, Manassas, VA, U.S.A.), were cultured in Dulbecco's modified Eagle's medium (DMEM) containing $5 \%$ fetal bovine serum (Hyclone Laboratories Inc., Logan, UT, U.S.A.) and antibiotics at $37^{\circ} \mathrm{C}$ in a humidified incubator

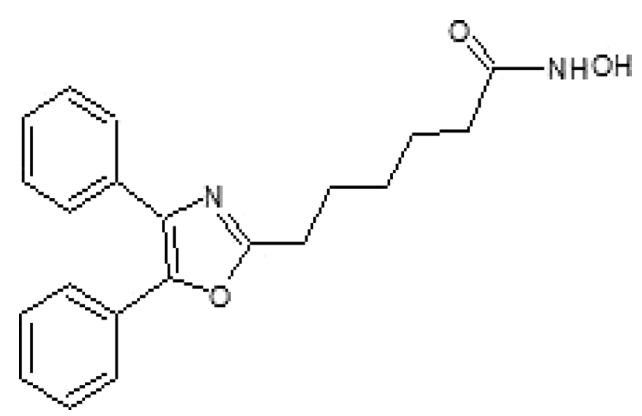

Fig. 1. Chemical Structure of SK-1009 
with $5 \% \mathrm{CO}_{2}$. The IL-6 suppressor SK-1009, $N$-hydroxy-4,5diphenyl-2-oxazolehexanamide, was chemically synthesized at Shizuoka Coffein Co., Ltd. Its structure is shown in Fig. 1. In vitro data showed that this compound reverse the inhibitory effects of LPS-induced IL-6 protein production in human macrophage cells, THP- 1 . $\mathrm{IC}_{50}$ for SK-1009 is $2.7 \times 10^{-7} \mathrm{M}$, and was reported in international patent WO2007/091313. TNF $\alpha$ was purchased from PEPROTECH (Rock Hill, NJ, U.S.A.), $\mathrm{NF}-\kappa \mathrm{B}$ inhibitors, 5HPP-33 and SM-7368 was purchased from Merck KGaA (Darmstadt, Germany). Catechin, dexamethasone and troglitazone were purchased from Sigma-Aldrich (St. Louis, MO, U.S.A.).

Cell Viability Determined by 3-(4,5-Dimethylthiazol2-yl)-2,5-diphenyltetrazolium Bromide (MTT) Assay An hour before the end of treatment with TNF $\alpha$ and SK-1009, $0.5 \mathrm{mg} / \mathrm{mL}$ of MTT was added to the medium and incubated. The MTT formazan produced by living cells was dissolved with dimethyl sulfoxide and the absorbance at $590 \mathrm{~nm}$ was measured on a microplate reader.

Real-Time Polymerase Chain Reaction (PCR) Analysis Total RNA was isolated from cells using Isogen (Nippon Gene, Tokyo, Japan), treated with DNase (Invitrogen, Grand Island, NY, U.S.A.) and $3 \mu \mathrm{g}$ aliquots in a final volume of $20 \mu \mathrm{L}$ were used for synthesis of cDNA using an Omniscript RT Kit (Qiagen, Hilden, Germany) and randomized primer. Real-time PCR was carried out using a DNA Engine Opticon TM 2 (MJ Research, Waltham, MA, U.S.A.) with SYBR Green Realtime PCR Master Mix (Toyobo Co., Osaka, Japan) according to the manufacturer's instructions. Primers for IL-6 (5'-AAA CAA CCT GAA CCT TCC AAA GA, 3'-GCA AGT CTC CTC ATT GAA TCCA), TNF $\alpha$ (5'-GAG GCC AAG CCC TGG TAT G， 3'-CGGGCCGAT TGA TCTCAGC) and glyceraldehyde-3-phosphate dehydrogenase (GAPDH) (5'-TTG CCA TCA ATG ACC CCT TCA, 3'-CGC CCC ACT TGA TTT TGGA) were employed. To assess the specificity of each primer set, amplicons generated from the PCR reaction were analyzed for melting curves and also by electrophoresis in $2 \%$ agarose gels.

Luciferase Assay for NF- $\boldsymbol{B}$ Transcriptional Activity To measure NF- $\kappa \mathrm{B}$ transcriptional activity, colon cancer cell lines HCT116, RKO and SW480 were seeded in 96-well plates $\left(2 \times 10^{4}\right.$ cells/well). After $24 \mathrm{~h}$ incubation, cells were transiently transfected with $25 \mathrm{ng} /$ well of pGL4.32 [luc2P/NF- $\kappa \mathrm{kB} \mathrm{RE} /$ Hygro] (Promega Co., Madison, WI, U.S.A.) reporter plasmid and pGL4.73 [hRluc/SV40] (Promega) control plasmid using FuGENE $^{\circledR} 6$ Transfection Reagent (Roche Inc., Basel, Switzerland) according to the instructions provided by the manufacturer, and cultured for $24 \mathrm{~h}$. The cells were then treated with test agents, and finally Firefly luciferase and Renilla luciferase activities were determined by Luciferase Assay Systems and Renilla Luciferase Assay Systems (Promega), respectively. Basal luciferase activity of untreated cells was set as 1.0. The percent luciferase activity with each treatment was calculated from data for triplicate wells. The value was normalized by Renilla luciferase activity. All experiments were repeated at least three times with nearly identical results. Data are expressed as means \pm S.D. $(n=3)$.

Experiment for the Effects of Test Compounds on NF- $\kappa$ B Transcriptional Activity Plasmid-transfected HCT116, RKO and SW480 cells were cultured in the presence of $25 \mathrm{ng} /$ $\mathrm{mL} \mathrm{TNF} \alpha$ for 2 or $6 \mathrm{~h}$ after $30 \mathrm{~min}$ incubation with 25,50 ,
$100 \mu \mathrm{M}$ SK-1009. Similarly, 5HPP-33 (25, $50 \mu \mathrm{M})$, SM-7368 (25, $50 \mu \mathrm{M})$, catechin $(100 \mu \mathrm{M})$, dexamethasone $(10 \mu \mathrm{M})$ and troglitazone $(10 \mu \mathrm{M})$ were added to the medium $30 \mathrm{~min}$ before $\mathrm{TNF} \alpha$ stimulation. NF- $\kappa \mathrm{B}$ transcriptional activity was normalized for transfection rate calculated by SV40 promoter driven Renilla luciferase.

Immunofluorescence Analysis in Cells HCT116, RKO and SW480 cells were seeded at a density of $8 \times 10^{4} /$ well in 8 -chamber slides, and incubated in the presence or absence of $25 \mu \mathrm{g} / \mathrm{mL} \mathrm{TNF} \alpha$ for $30 \mathrm{~min}$ after $30 \mathrm{~min}$ pretreatment with or without $50 \mu \mathrm{M}$ SK-1009. After incubation, cells were fixed with $2 \%$ paraformaldehyde for $30 \mathrm{~min}$ at room temprature and permeabilized with methanol for $10 \mathrm{~min}$ at $-20^{\circ} \mathrm{C}$. Cells were subjected to immunofluorescence analysis with anti-NF- $\kappa \mathrm{B}$ (p65) antibodies (Santa Cruz Biotechnology Inc., Santa Cruz, CA, U.S.A.) at 1:100 dilutions followed by anti-rabbit immunoglobulin $\mathrm{G}$ ( $\mathrm{IgG}$ ) fluorescein isothiocyanate (FITC) conjugated antibody (Biotium, Hayward, CA, U.S.A.).

Sodium Dodecyl Sulfate-Polyacrylamide Gel Electrophoresis (SDS-PAGE) and Western Blot Analysis The cells were lysed in SDS sample buffer solution $(62.5 \mathrm{~mm}$ Tris- $\mathrm{HCl}$, $\mathrm{pH} 6.8,2 \%$ SDS, 5\% 2-mercaptoethanol, 10\% glycerol) and the lysates were briefly sonicated and boiled for $5 \mathrm{~min}$. Proteins from lysates of HCT116, RKO and SW480 cells were separated on polyacrylamide gels and electrophoretically transferred to Immobilon-P membranes (Merck Millipore, Billerica, MA, U.S.A.). After blocking with $2 \%$ non-fat skim milk in TTBS (10 mM Tris- $\mathrm{HCl}, \mathrm{pH} 7.5,140 \mathrm{~mm} \mathrm{NaCl}, 0.05 \%$ Tween 20) for $1 \mathrm{~h}$ the membranes were incubated with primary antibody in TTBS containing $1 \%$ bovine serum albumin, washed with TTBS and incubated with the second antibody, horseradish peroxidase-conjugated anti-rabbit or anti-mouse IgG (Amersham Bioscience, Little Chalfont, U.K.). After further washing with TTBS the blots were developed using an ECL detection kit (GE Healthcare, Little Chalfont, U.K.) and exposed to Kodak XAR-5 film (Eastman Kodak Co., Rochester, NY, U.S.A.). The antibodies were stripped by placing the blots in boiling water for several minutes and then the blots were re-probed with further antibodies: mouse monoclonal anti- $\beta$ actin (Sigma Life Science, St Louis, MO, U.S.A.) and rabbit polyclonal anti-I- $\kappa \mathrm{B} \alpha$ antibody (Santa Cruz Biotechnology Inc.).

Transcriptional Factor Activation Profiling Analysis Activation of several receptors, such as androgen receptor (AR), constitutive active/androstane receptor (CAR), estrogen receptor (ER), glucocorticoid receptor (GR), hepatocyte nuclear factor-4 (HNF4), peroxisome proliferator-activated receptor (PPAR) and pregnane X receptor (PXR) by SK-1009 in HCT-116 cells were evaluated using Transcriptional Factor Activation Profiling Array (Signosis, Inc., Sunnyvale, CA, U.S.A.). HCT116 cells $\left(3 \times 10^{6}\right.$ cells/well $)$ were cultured with or without $50 \mu \mathrm{M}$ SK-1009 for $6 \mathrm{~h}$, and then nuclear extracts were obtained by a Nuclear/Cytsol Fraction Kit (BioVision, Milpitas, CA, U.S.A.). Nuclear extracts were incubated with consensus sequences of nuclear receptor DNA-binding sites for determination of transcriptional activities according to the manufacturer's protocol.

Statistical Analysis All the results are expressed as mean \pm S.D. values, with statistical analysis using Bonferroni $z$-test. Differences were considered to be statistically significant at $p<0.05$. 
A

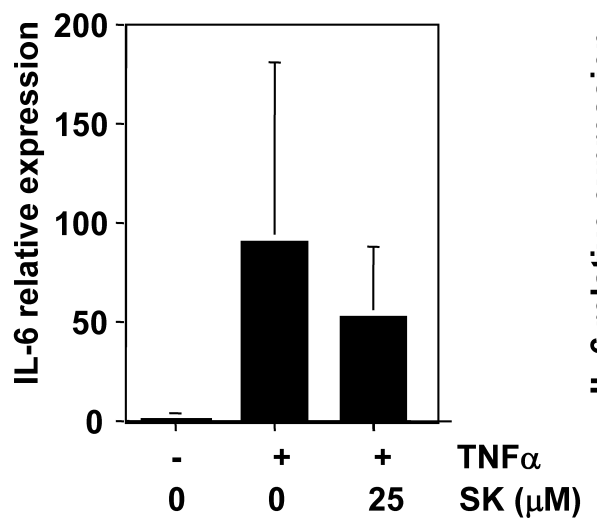

B

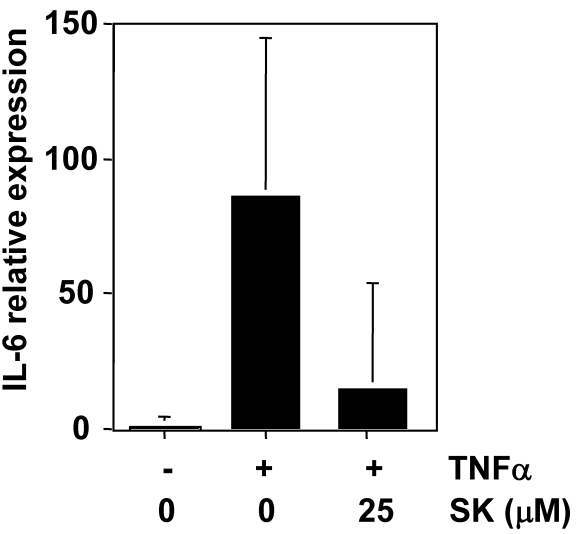

C

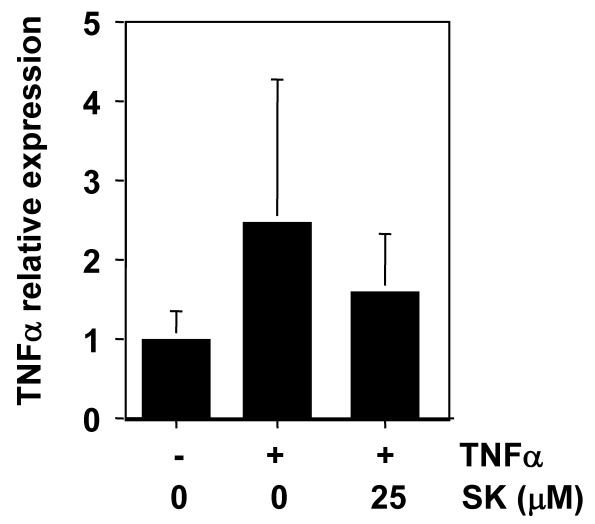

D

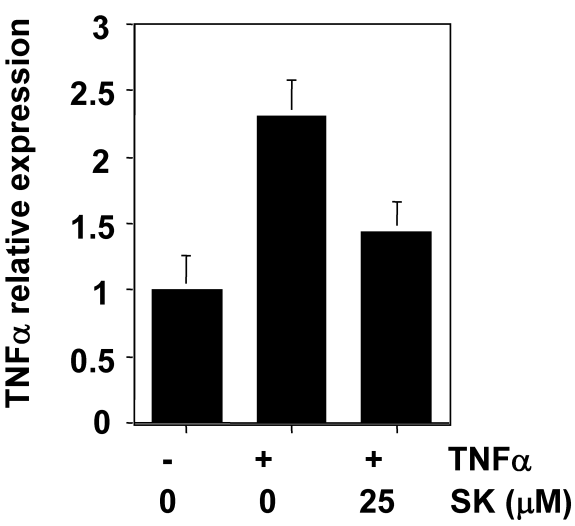

Fig. 2. Effects of SK-1009 on Various Cytokine mRNA Levels

HCT116 (A, C) and RKO (B, D) cells were cultured with and without $25 \mathrm{ng} / \mathrm{mL}$ TNF $\alpha$ for $6 \mathrm{~h}$ after 30 min incubation with $25 \mu \mathrm{M}$ SK-1009 (SK). Relative IL-6 (A, B) and $\mathrm{TNF} \alpha(\mathrm{C}, \mathrm{D})$ mRNA expression levels are plotted as the ratio of the unstimulated control culture value. Data are means \pm S.D. $(n=3)$. Similar results were obtained from more than three separate experiments.

\section{RESULTS}

Suppression of Cytokine Expression by SK-1009 in TNF $\alpha$-Stimulated Human Colon Cancer Cells To confirm that SK-1009 suppresses IL-6 expression levels in colon epithelial cells, HCT116 and RKO cells were stimulated with $25 \mathrm{ng} / \mathrm{mL}$ TNF $\alpha$ to induce IL- 6 and TNF $\alpha$ mRNA and simultaneously incubated with $25 \mu \mathrm{M}$ SK-1009. As shown in Fig. 2, SK-1009 treatment suppressed IL-6 and TNF $\alpha$ mRNA levels in $\mathrm{TNF} \alpha$-stimulated cells.

Inhibition of TNF $\alpha$-Treated NF- $\kappa$ B Transcriptional Activity by SK-1009 in Human Colon Cancer Cells NF- $\kappa \mathrm{B}$ is the major transcriptional factor responsible for induction of $I L-6$ gene expression induced by LPS and inflammatory cytokines. Thus, we assumed that the one of the targets of SK-1009 is NF- $\kappa$ B, and examined the effects of SK-1009 on $\mathrm{TNF} \alpha$-activated NF- $\kappa \mathrm{B}$ transcriptional activity using luciferase reporter gene assay. No significant difference was observed in the basal NF- $\kappa \mathrm{B}$ transcriptional activity of HCT116 cells between serum-deprived cultures and 5\% fetal bovine serum (FBS)-supplemented cultures after $6 \mathrm{~h}$. To examine the effective dose and timing of $\mathrm{TNF} \alpha$, cells were cultured in a medium containing 5, 25 and $100 \mathrm{ng} / \mathrm{mL}$ TNF $\alpha$ without FBS, and NF- $\kappa \mathrm{B}$ transcriptional activity were tested. Treatment of HCT116 cells with 5, 25 and $100 \mathrm{ng} / \mathrm{mL} \mathrm{TNF} \alpha$ for
$6 \mathrm{~h}$ increased the activity to almost 7, 12 and 13 times of the control value, respectively (Suppl. Fig. 1A). NF- $\kappa$ B transcriptional activities after $6 \mathrm{~h}$ treatment with TNF $\alpha$ were elevated compared to those of $2 \mathrm{~h} \mathrm{TNF} \alpha$ treatment in RKO cells and SW480 cells (Suppl. Figs. 1B,C). Moreover, TNF $\alpha$ seems to activate NF- $\kappa \mathrm{B}$ transcriptional activities to its maximum at the dose of $25 \mathrm{ng} / \mathrm{mL}$ (Suppl. Fig. 1). No significant decrease of cell viability, evaluated by MTT assay, was observed after $6 \mathrm{~h}$ culture with TNF $\alpha$ at these concentrations.

The effects of SK-1009 on TNF $\alpha$-stimulated NF- $\kappa \mathrm{B}$ transcriptional activity were next examined, and revealed that SK-1009 significantly suppressed TNF $\alpha$-stimulated NF- $\kappa \mathrm{B}$ transcriptional activity in a dose-dependent manner (Fig. 3). Decreases in $\mathrm{TNF} \alpha$-stimulated NF- $\kappa \mathrm{B}$ transcriptional activity at the highest doses of SK-1009 were as follows; $64 \%$ for HCT116 cells, $42 \%$ for RKO cells and $59 \%$ for SW 480 cells (Figs. 3A-C). No significant decrease of cell viability, evaluated by Renilla luciferase activity obtained from Renilla Luciferase Assay Systems and MTT assay, was observed after $6 \mathrm{~h}$ culture with TNF $\alpha$ plus SK-1009 at these concentrations. MTT assay revealed less than $4 \%$ decrease of cell viability in TNF $\alpha$ plus SK-1009 treatment compared with TNF $\alpha$ alone.

Inhibition of TNF $\alpha$-Induced NF- $\kappa$ B Nuclear Translocation and Degradation of the Inhibitory Subunit I- $\boldsymbol{I} \mathrm{B} \alpha$ by SK-1009 Treatment Translocation of NF- $\kappa \mathrm{B}$ to the 
A

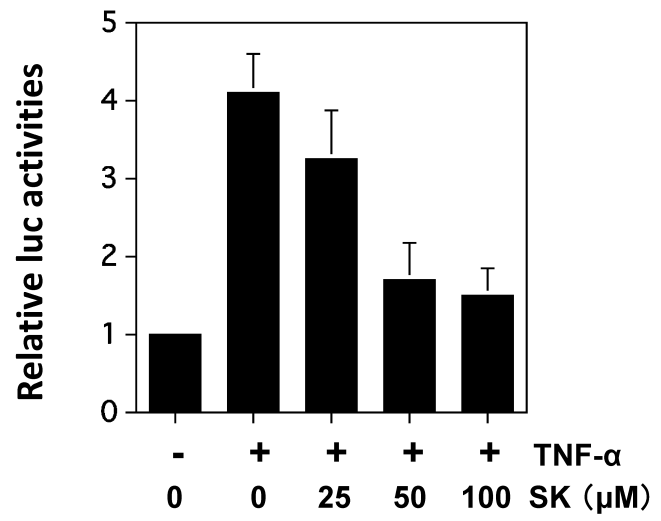

B

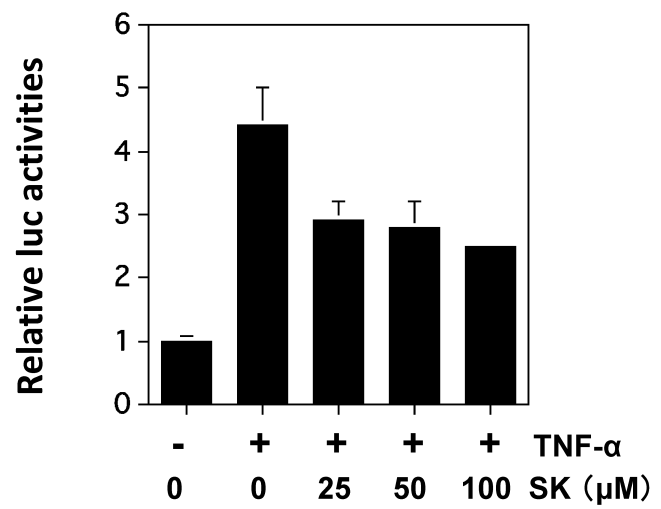

C

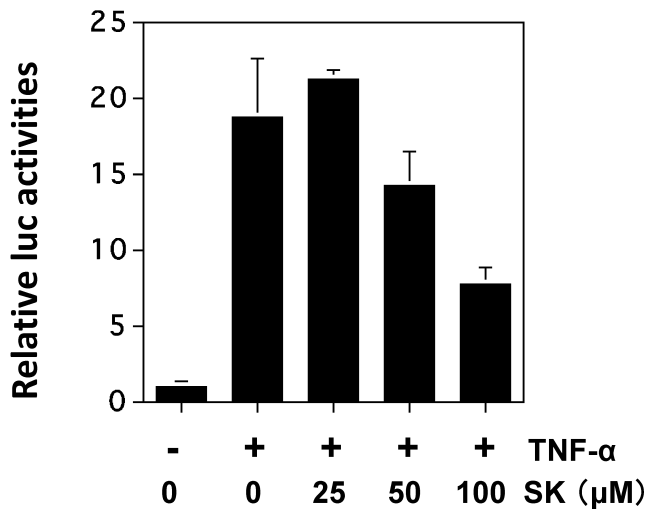

Fig. 3. Effects of SK-1009 on TNF $\alpha$-Treated NF- $\kappa \mathrm{B}$ Transcriptional Activity in Human Colon Cancer Cells

HCT116 (A), RKO (B) and SW480 (C) cells were cultured in the presence of $25 \mathrm{ng} / \mathrm{mL} \mathrm{TNF} \alpha$ for $6 \mathrm{~h}$ after $30 \mathrm{~min}$ incubation with the indicated dose of SK-1009. Relative NF- $\kappa$ B transcriptional activities are plotted as the ratio of the unstimulated control culture value. Data are means \pm S.D. $(n=3)$. Similar results were obtained from three separate experiments.

nucleus activates transcription of NF- $\kappa$ B-responsive genes. Thus, we performed fluorescent immunohistochemical analysis of NF- $\kappa \mathrm{B}$ subcellular localizations after $\mathrm{TNF} \alpha$ treatment in HCT116 cells. TNF $\alpha$ caused NF- $\kappa$ B nuclear translocation within $30 \mathrm{~min}$ (Figs. $4 \mathrm{~A}-\mathrm{C}$ ) and this was prevented by $50 \mu \mathrm{M}$ SK-1009 pretreatment for $30 \mathrm{~min}$. Similar results were obtained in SW480 cells, but failed in RKO cells (data not shown).

Translocation of NF- $\kappa \mathrm{B}$ to the nucleus is preceded by phosphorylation and proteolytic degradation of the inhibitory subunit I- $\kappa \mathrm{B} \alpha$. To determine whether the effect of SK-1009 on NF- $\kappa \mathrm{B}$ activation is related to $\mathrm{I}-\kappa \mathrm{B} \alpha$ degradation, the $\mathrm{I}-\kappa \mathrm{B} \alpha$ protein level was examined by Western blot analysis.
As shown in Fig. 4D, stimulation of the HCT116 cells with $\mathrm{I}-\kappa \mathrm{B} \alpha$ caused a rapid decrease in the abundance of $\mathrm{I}-\kappa \mathrm{B} \alpha$ protein, which almost completely disappeared in stimulated cells $10-30 \mathrm{~min}$ after $\mathrm{I}-\kappa \mathrm{B} \alpha$ stimulation. Similar results were obtained in SW480 cells (data not shown). However, I- $\kappa \mathrm{B} \alpha$ degradation was weakly observed in RKO cells (Fig. 4E).

Effects of NF- $\kappa$ B Inhibitors on TNF $\alpha$-Treated NF- $\kappa$ B Transcriptional Activity in HT116 Cells The effects of the available NF- $\kappa$ B inhibitors on TNF-stimulated NF- $\kappa$ B transcriptional activity were examined for the comparison of their potential to those of SK-1009. All the NF- $\kappa$ B inhibitors significantly suppressed $\mathrm{TNF} \alpha$-stimulated $\mathrm{NF}-\kappa \mathrm{B}$ transcriptional activity in a dose-dependent manner. Decreases in TNF $\alpha$ stimulated NF- $\kappa \mathrm{B}$ transcriptional activity at a dose of $50 \mu \mathrm{M}$ were as follows; $67 \%$ for SK-1009, 65\% for 5HPP-33 and $96 \%$ for SM-7368 (Fig. 5). SM-7368 showed the strongest inhibition and similar inhibitory potential were observed between SK-1009 and 5HPP-33.

Effects of SK-1009 on Activation of Nuclear Receptor Subfamily, Including Xenobiotic Receptors To examine the possibility that SK-1009 could be the ligand for other receptors that affect NF- $\kappa \mathrm{B}$ transcriptional activity, we evaluated direct activation of several nuclear receptors, such as AR, CAR, ER, GR, HNF4, PPAR and PXR by SK-1009 in HCT-116 cells, and found no activation was observed in such receptors (Suppl. Fig. 2A). Furthermore, the effects of several agents that regulate xenobiotic metabolism, on TNF $\alpha$ stimulated NF- $\kappa \mathrm{B}$ transcriptional activity in HCT-116 cells were examined. HCT-116 cells were treated with SK-1009 catechin, troglitazone and dexamethasone for $2 \mathrm{~h}$, and it was found that only SK-1009 reduced TNF $\alpha$-stimulated NF- $\kappa \mathrm{B}$ transcriptional activity (Suppl. Fig. 2B). After 6h, dexamethasone tend to reduce $\mathrm{TNF} \alpha$-stimulated $\mathrm{NF}-\kappa \mathrm{B}$ transcriptional activity (data not shown). These data demonstrated that the effects of SK-1009 on NF- $\kappa$ B transcriptional activity is faster than that of dexamethasone, and suggested that the effect of SK-1009 is not the result of activation of xenobiotic receptor, such as pregnane $\mathrm{X}$ receptor.

\section{DISCUSSION}

The present study demonstrated that SK-1009 significantly suppresses $I L-6$ expression levels not only in human macrophage cells, but also in human colon cancer cells stimulated with TNF $\alpha$. Moreover, we demonstrated clear suppression of activation of transcription factor NF- $\kappa \mathrm{B}$, which has important roles in $I L-6$ gene expression with SK-1009 treatment.

Many kinds of transcription factors are known to be involved in transcriptional induction of the $I L-6$ gene, such as $\mathrm{NF}-\kappa \mathrm{B}$ and NF-IL6. Of these, NF- $\kappa \mathrm{B}$ is the major transcription factor responsible for induction of the $I L-6$ gene expression by LPS and inflammatory cytokines. ${ }^{13-15)}$ The NF- $\kappa$ B binding site located between -72 and -63 on the $I L-6$ gene promoter region is important for IL-6 induction. ${ }^{16-18)}$ Both p50 and p65 can bind strongly to the $\kappa \mathrm{B}$-like motif of the $I L-6$ gene. IL- 6 promoter-luciferase reporter gene assay with a site-directed mutant revealed that both NF-IL6 and NF- $\kappa$ B binding sites in the $I L-6$ gene are required for the synergistic activation. ${ }^{19)}$ Thus, we speculated that SK-1009 has the potential to inhibit NF- $\kappa \mathrm{B}$ transcriptional activity. In addition, SK-1009 suppressed the expression of several inflammation-related genes including 

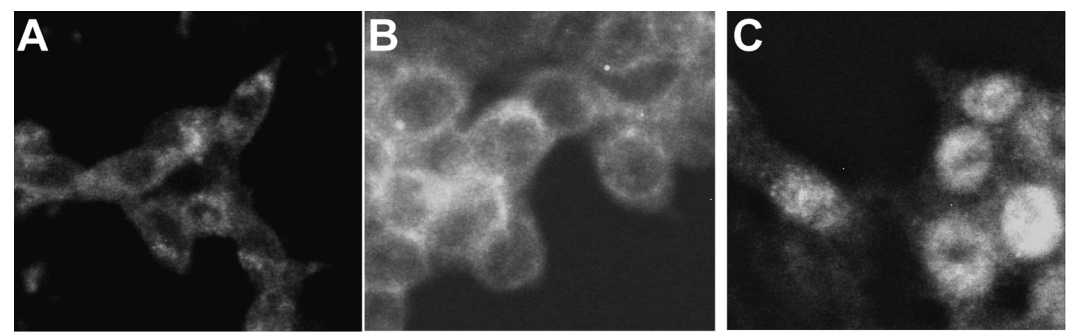

D

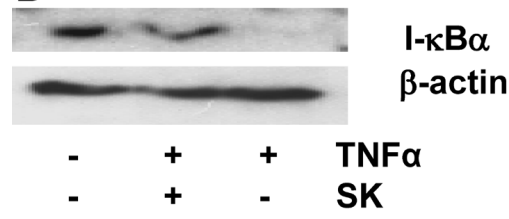

E

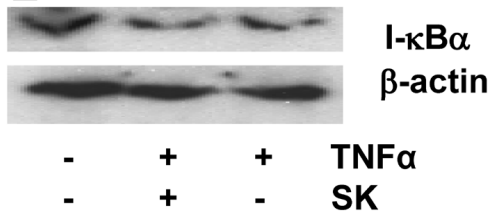

Fig. 4. Effects of SK-1009 on Nuclear Translocation of NF- $\kappa$ B and I-kB $\alpha$ Degradation

HCT116 cells were pre-treated with $50 \mu \mathrm{M}$ SK-1009, and then $25 \mathrm{ng} / \mathrm{mL}$ TNF $\alpha$ were treated with for 30 min. After treatment, cells were fixed with $2 \%$ paraformaldehyde and fluorescent immunohistochemical analysis of NF- $\kappa$ B was performed. Control un-treated cells (A), SK-1009 plus TNF $\alpha$ treated cells (B) and TNF $\alpha$ treated cells (C). The data shown are representative of two independent experiments. Western blot analysis of I- $\kappa \mathrm{B} \alpha$ protein levels after 0 and $30 \mathrm{~min}$ incubation with $25 \mathrm{ng} / \mathrm{mL}$ TNF $\alpha$ with or without $50 \mu \mathrm{M}$ SK-1009 in HCT116 cells (D) and RKO cells (E). Cell lysate proteins were separated on a $15 \%$ SDS-polyacrylamide gel. The data shown are representative of two independent experiments.

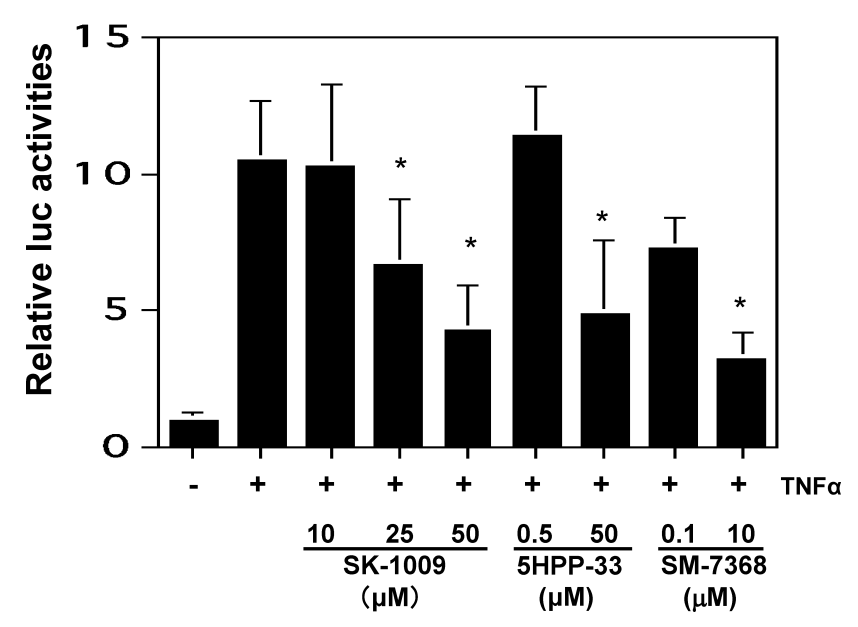

Fig. 5. Effects of NF- $\kappa \mathrm{B}$ Inhibitors on $\mathrm{TNF} \alpha$-Treated NF- $\kappa \mathrm{B}$ Transcriptional Activity in HCT116 Cells

HCT116 cells were cultured in the presence of $25 \mathrm{ng} / \mathrm{mL}$ TNF $\alpha$ for $6 \mathrm{~h}$ after $30 \mathrm{~min}$ incubation with the indicated dose of NF- $\kappa \mathrm{B}$ inhibitors, 5HPP-33 or SM-7368. Relative NF- $\kappa$ B transcriptional activities are plotted as the percentage of the unstimulated control culture value. Data are means \pm S.D. $(n=3) . * p<0.05$ vs. TNF $\alpha$ treatment. Similar results were obtained from two separate experiments.

cytokines, such as TNF $\alpha$ and IL-8 (data not shown), in which $\mathrm{NF}-\kappa \mathrm{B}$ plays an important role in its induction. These results support the data that NF- $\kappa$ B could be the target of SK-1009. Meanwhile, not all the IL-6 suppressive effect can't be explained by reduction of NF- $\kappa \mathrm{B}$ transcriptional activity, such as that which was observed in RKO cells. We also examined the effects of nuclear receptor activation by SK-1009, but did not obtain data suggesting cross talk between NF- $\kappa \mathrm{B}$ transcriptional activity and such nuclear receptors as far as we could find. Further detailed mechanisms underlying suppression of $\mathrm{NF}-\kappa \mathrm{B}$ transcriptional activity by SK-1009 should be examined in the future.

The importance of NF- $\kappa \mathrm{B}$ is demonstrated by its critical role in responses leading to host defense through rapid induction of several genes, such as inflammatory and immunological responses. ${ }^{20,21)}$ Dysregulation of NF- $\kappa \mathrm{B}$ has been linked to pathological dysregulation of various conditions, including inflammatory reactions, septicshock, acquired immunodeficiency syndrome and cancer. ${ }^{20,21)}$ The NF- $\kappa$ B protein exists in the cytoplasm in an inactive state with an inhibitory subunit I $-\kappa \mathrm{B} \alpha$. Phosphorylation of residues Ser32 and Ser36 of $\mathrm{I}-\kappa \mathrm{B} \alpha$ and its subsequent degradation allows nuclear translocation of NF- $\kappa \mathrm{B}$. Translocation of NF- $\kappa \mathrm{B}$ to the nucleus activates transcription of NF- $\kappa \mathrm{B}$ responsive genes, ${ }^{22,23)}$ such as IL-6 and TNF $\alpha$. Thus, inhibition of NF- $\kappa$ B by SK-1009 was suggested to be, at least in part, due to inhibition of degradation of I- $\kappa \mathrm{B} \alpha$ (Fig. 4). Roles for reactive oxygenspecies, protein kinases, protein phosphatases, proteases and ceramide have been documented in the pathway of $\mathrm{I}-\kappa \mathrm{B} \alpha$ degradation and NF- $\kappa \mathrm{B}$ activation. $^{20,21)}$ SK-1009 is so novel a compound that the effects on such reactive oxygenspecies production, activation of protein kinases, protein phosphatases, proteases and ceramide are not known yet. Further studies need to be carried out to elucidate the effects of SK-1009 on the pathway of inhibition of degradation of $\mathrm{I}-\kappa \mathrm{B} \alpha$.

Evidence is now accumulating that excessive production of IL-6 is a causative factor for carcinogenesis. ${ }^{24-27)}$ Dysregulated activation of $\mathrm{NF}-\kappa \mathrm{B}$ has also been suggested to be related to promotion of carcinogenesis. ${ }^{20,21)}$ Therefore, SK-1009 inhibition of IL-6 production may be causally related to its anticarcinogenic potential. However, it should be borne in mind that NF- $\kappa \mathrm{B}$ activity also plays an important role in the immune system. Therefore, it is possible that pronounced inhibition of IL- 6 production and transcription factor activities in macrophages and lymphocytes may cause adverse effects, such as immunosuppression and deterioration of the defense system of the host, which may facilitate tumor growth. In order to clarify the applicability of SK-1009 as a cancer preventive agent, animal experiments are now under investigation. Our results have shown an additional candidate NF- $\kappa \mathrm{B}$ inhibitor, which could be a cancer preventive agent. 
Acknowledgements This work was supported by Grantsin-Aid for Cancer Research, for the Third-Term Comprehensive 10-Year Strategy for Cancer Control from the Ministry of Health, Labour, and Welfare of Japan, and also from the Yakult Bio-science Foundation.

\section{REFERENCES}

1) Tilg H, Moschen AR. Inflammatory mechanisms in the regulation of insulin resistance. Mol. Med., 14, 222-231 (2008).

2) Ishihara K, Hirano T. IL-6 in autoimmune disease and chronic inflammatory proliferative disease. Cytokine Growth Factor Rev., 13, 357-368 (2002).

3) Oshima H, Oshima M. The inflammatory network in the gastrointestinal tumor microenvironment: lessons from mouse models. $J$. Gastroenterol., 47, 97-106 (2012).

4) Mroczko B, Groblewska M, Gryko M, Kedra B, Szmitkowski M. Diagnostic usefulness of serum interleukin 6 (IL-6) and C-reactive protein (CRP) in the differentiation between pancreatic cancer and chronic pancreatitis. J. Clin. Lab. Anal., 24, 256-261 (2010).

5) Fuksiewicz M, Kowalska M, Kotowicz B, Rubach M, Chechlinska M, Pienkowski T, Kaminska J. Serum soluble tumour necrosis factor receptor type I concentrations independently predict prognosis in patients with breast cancer. Clin. Chem. Lab. Med., 48, 14811486 (2010).

6) Biggar RJ, Johansen JS, Smedby KE, Rostgaard K, Chang ET, Adami HO, Glimelius B, Molin D, Hamilton-Dutoit S, Melbye M, Hjalgrim H. Serum YKL-40 and interleukin 6 levels in Hodgkin lymphoma. Clin. Cancer Res., 14, 6974-6978 (2008).

7) Sharma R, Zucknick M, London R, Kacevska M, Liddle C, Clarke SJ. Systemic inflammatory response predicts prognosis in patients with advanced-stage colorectal cancer. Clin. Colorectal Cancer, 7, 331-337 (2008)

8) Lutgendorf SK, Weinrib AZ, Penedo F, Russell D, DeGeest K, Costanzo ES, Henderson PJ, Sephton SE, Rohleder N, Lucci JA 3rd, Cole S, Sood AK, Lubaroff DM. Interleukin-6, cortisol, and depressive symptoms in ovarian cancer patients. J. Clin. Oncol., 26, 4820-4827 (2008).

9) Baltgalvis KA, Berger FG, Pena MM, Davis JM, Muga SJ, Carson JA. Interleukin-6 and cachexia in ApcMin/+ mice. Am. J. Physiol. Regul. Integr. Comp. Physiol., 294, R393-R401 (2008).

10) Teraoka N, Mutoh M, Takasu S, Ueno T, Yamamoto M, Sugimura $\mathrm{T}$, Wakabayashi K. Inhibition of intestinal polyp formation by pitavastatin, a HMG-CoA reductase inhibitor. Cancer Prev. Res. (Phila.), 4, 445-453 (2011).

11) Barton BE. Interleukin- 6 and new strategies for the treatment of cancer, hyperproliferative diseases and paraneoplastic syndromes. Expert Opin. Ther. Targets, 9, 737-752 (2005).

12) Smolen JS, Maini RN. Interleukin-6: a new therapeutic target. $A r-$ thritis Res. Ther., 8 (Suppl. 2), S5 (2006).

13) Xie QW, Whisnant R, Nathan C. Promoter of the mouse gene encoding calcium-independent nitric oxide synthase confers inducibil- ity by interferon gamma and bacterial lipopolysaccharide. J. Exp. Med., 177, 1779-1784 (1993).

14) Xie QW, Kashiwabara $Y$, Nathan C. Role of transcription factor NFkappaB/Rel in induction of nitric oxide synthase. J. Biol. Chem., 269, 4705-4708 (1994).

15) Gao J, Morrison DC, Parmely TJ, Russell SW, Murphy WJ. An interferon-gamma-activated site (GAS) is necessary for full expression of the mouse iNOS gene in response to interferon-gamma and lipopolysaccharide. J. Biol. Chem., 272, 1226-1230 (1997).

16) Shimizu H, Mitomo K, Watanabe T, Okamoto S, Yamamoto K. Involvement of a NF-kappaB-like transcription factor in the activation of the interleukin- 6 gene by inflammatory lymphokines. Mol. Cell. Biol., 10, 561-568 (1990).

17) Libermann TA, Baltimore D. Activation of interleukin-6 gene expression through the NF-kappaB transcription factor. Mol. Cell. Biol., 10, 2327-2334 (1990).

18) Zhang YH, Lin JX, Vilcek J. Interleukin-6 induction by tumor necrosis factor and interleukin-1 in human fibroblasts involves activation of a nuclear factor binding to a kappaB-like sequence. Mol. Cell. Biol., 10, 3818-3823 (1990).

19) Matsusaka T, Fujikawa K, Nishio Y, Mukaida N, Matsushima K, Kishimoto T, Akira S. Transcription factors NF-IL6 and NF-kappa B synergistically activate transcription of the inflammatory cytokines, interleukin 6 and interleukin 8. Proc. Natl. Acad. Sci. U.S.A., 90, 10193-10197 (1993).

20) Barnes PJ, Karin M. Nuclear factor-kappaB: a pivotal transcription factor in chronic inflammatory diseases. N. Engl. J. Med., 336, 1066-1071 (1997).

21) Siebenlist U, Franzoso G, Brown K. Structure, regulation and function of NF- $\kappa$ B. Annu. Rev. Cell Biol., 10, 405-455 (1994).

22) Henkel $T$, Machleidt $T$, Alkalay I, Krönke M, Ben-Neriah $Y$, Baeuerle PA. Rapid proteolysis of I kappaB-alpha is necessary for activation of transcription factor NF-kappaB. Nature, 365, 182-185 (1993).

23) Brown K, Gerstberger S, Carlson L, Franzoso G, Siebenlist U. Control of I kappa B-alpha proteolysis by site-specific, signal-induced phosphorylation. Science, 267, 1485-1488 (1995).

24) Wink DA, Kasprzak KS, Maragos CM, Elespuru RK, Misra M, Dunams TM, Cebula TA, Koch WH, Andrews AW, Allen JS, Keefer LK. DNA deaminating ability and genotoxicity of nitric oxide and its progenitors. Science, 254, 1001-1003 (1991).

25) Liu RH, Jacob JR, Hotchkiss JH, Cote PJ, Gerin JL, Tennant BC. Woodchuck hepatitis virus surface antigen induces nitric oxide synthesis in hepatocytes: possible role in hepatocarcinogenesis. Carcinogenesis, 15, 2875-2877 (1994).

26) Ohshima H, Bartsch H. Chronic infections and inflammatory processes as cancer risk factors: possible role of nitric oxide in carcinogenesis. Mutat. Res., 305, 253-264 (1994).

27) Haswell-Elkins MR, Satarug S, Tsuda M, Mairiang E, Esumi H, Sithithaworn P, Mairiang P, Saitoh M, Yongvanit P, Elkins DB. Liver fluke infection and cholangiocarcinoma: model of endogenous nitric oxide and extragastric nitrosation in human carcinogenesis. Mutat. Res., 305, 241-252 (1994). 